\title{
A polgári védelem szervezeti struktúrájának és háborús feladatrendszerének változása a jogszabályok tükrében
}

\section{Changes in the Organisation Structure and War Task System of the Civil Protection under the Legislation}

A védelmi szakemberek szerint, hazánk egységes védelmi rendszerébe tartozó polgári védelemnek rendelkeznie kell olyan lakosságvédelmi tervekkel, eljárásokkal és módszerekkel, amelyek túlmutatnak egy „,békeidős” katasztrófahelyzetben végrehajtandó feladatokon, valamint képesnek kell lennie arra, hogy az Alaptörvény Különleges Jogrendi időszak katonai jellegü válságai során, a vele szemben támasztott követelményeknek is megfeleljen. A szerzö, ebben a cikkbenjogszabályok elemzése alapján bemutatja a fegyveres összeütközés miatt szükségessé váló polgári védelmifeladatokat, vizsgálja, hogy a jelenlegi jogszabályi háttér megfelelöen rögzíti-e a szervezet háborús feladatrendszerét. Továbbá, ezzel összefüggésben, kutatja a háborús védelmi tervek és a szakmai eljárásrendek kidolgozásának jelenlegi helyzetét.

Kulcsszavak: polgári védelem, honvédelem rendszere, háborús feladatrendszer, logisztika, polgári védelmi feladatok

In his article, the author presents the civil protection tasks required by armed conflict on the basis of an analysis of the legislation, examines whether the current legal background appropriately fixes the organisation's war task system. In addition, he is researching the current state of development of war defence plans and professional procedures, as well as the existence of state provisions, the possibility and conditions of their use.

Keywords: civil protection, defence system, war task system, civil protection tasks

Nemzeti Közszolgálati Egyetem, Rendvédelmi Tagozat, kiképző, Nemzeti Közszolgálati Egyetem Katonai Műszaki Doktori Iskola, PhD-jelölt, e-mail: horvath_zoltan@uni-nke.hu; ORCID: 0000-0002-8505-5339 


\section{Bevezetés}

Pataki Iván a hadtudományok kandidátusa 1998-ban A polgári védelem a honvédelem rendszerének alkotóeleme címü cikkében egy napjainkban is aktuális megállapítást tesz, amely szerint az 1990-es évektől alapvetően a polgári védelem béke- és katasztrófavédelmi feladatai kerültek előtérbe, a háborús feladatairól és a honvédelemben betöltött szerepéről egyre kevesebb szó esik. Pedig a szervezetet a háború hívta életre és ennek veszélye jelenleg sem múlt el, csak a fegyveres küzdelem jellege változott meg. Ezt erősítette meg Benkő Tibor vezérezredes, a Honvéd Vezérkar fönöke egy 2014-ben megjelent cikkben: „[T]ény, hogy - mint azt a nemzeti katonai stratégia is rögzíti - Magyarország egyetlen államot sem tekint ellenségének, ugyanakkor a környező országokban jelentkező békétlenségek kihathatnak Magyarországra is. Elég csak a kilencvenes évek délszláv válságára gondolni, amely nagyon gyorsan következett be, és most is egyik napról a másikra polgárháborús helyzet alakult ki a szomszédos Ukrajnában." ${ }^{2}$

Egy ország számára a legnagyobb civilizációs katasztrófát a háború jelenti, amely elpusztíthatja a lakóépületeket, a közlekedési rendszereket, az ipari létesítményeket az infrastruktúrahálózatot, a történelmi-, kulturális örökségét, és visszafordíthatatlan károkat okoz az emberek lelkében, pszichés állapotában.

A felelősségteljesen gondolkodó állami és politikai vezetők mindent megtesznek annak érdekében, hogy elkerüljék a fegyveres küzdelem kialakulását, ugyanakkor számolnak azzal, hogy bekövetkezhet egy olyan rendkívüli esemény, amely súlyosan veszélyeztetheti az emberek életét, az anyagi javak és az ország biztonságát. Tisztában vannak azzal, hogy ezek hatásainak kezelésére fel kell készülni, ezért létrehozzák azokat a védelmi struktúrákat, szervezeteket, amelyek biztosítják az ország és a lakosság szükséges és elégséges védelmi szintjét, továbbá kialakítják a végrehajtást segítő tervezési, szervezési rendszereket, bevezetik a működést biztosító intézkedéseket, jogszabályi előírásokat. Lakatos László 2014-ben a Különleges jogrend és a honvédelem rendszere című tanulmányában fogalmazta meg, hogy a jogállamok müködésének is vannak különleges esetei, amikor a normál (béke-) időszaki jogrendtől eltérő államhatalmi szervezeti és működési rend alkalmazása válik szükségessé. Ez egy müködő biztonsági- és védelmi rendszert feltételez, a társadalom életét, az állam müködését, az állampolgárok élet- és vagyonbiztonságát fenyegető természeti vagy társadalmi eredetű veszélyek elhárítása érdekében. ${ }^{3}$

Egy háború következményei nem csupán a frontokon harcoló, a hátországban szolgáló vagy hadifogságba került katonákat, hanem a hátországokban maradó civil lakosság tömegeit is sújtják. A hátországi lakosság megvédésének feladatai nem vonatkoztathatók el a fegyveres összeütközésre való felkészülés feladataitól, ezért a lakosság védelmét is meg kell tervezni. A cikkben tárgyalt háborús polgári védelmi feladatok jelenlegi helyzetének jobb megértéséhez ismertetem a témát érintő legfontosabb szakirodalmi előzményeket és azok alapvető megállapításait.

Lapos Mihály A védelmi müveletek hadtápbiztositásáról írott munkáját elemezve két releváns felvetést kell kiemelni. Az első felvetés, hogy a védelem úgynevezett harcászati zónájának nagyságrendje 40-60 km, és ez alapján egyértelmüen meghatározhatók az érintett lakosság

https://mno.hu/belfold/benko-nem-szabad-tulzottan-nyugodtnak-lenni-1214892 (A letöltés dátuma: 2018. 04. 11.)

LAKATOS 2014, 1. 
és anyagi javak köre, mennyisége, elhelyezkedése. Mivel az ország egy háborús helyzetben, vagy fegyveres küzdelem esetén számíthat az ellenség csapásaira, ezért a lakosságvédelmi intézkedések végrehajtása az érintett zónában - de a zónán kívül is - elengedhetetlenné válik. Gondolni kell az ilyen területek kiürítésére, amelynek keretében az ipari és kulturális létesítményeket, az állam müködése szempontjából fontos intézményeket, valamint a közvetlenül érintett lakosságot az adott területről kivonják, és az áttelepített lakosság ellátását is egy új, a betelepítés helyszínén kell megszervezni. Másik felvetés, hogy a saját területen kiépítendő védelem lehetővé teszi a katonai, polgári és állami infrastruktúrák és készletek komplex igénybevételét. Ezért szükséges annak átgondolása és tervezése, hogy a szükséges anyagi, technikai eszközöket hogyan és hova szükséges kivonni, a további biztonságos felhasználás megvalósítása érdekében. ${ }^{4}$

Györök László $A$ hadszíntér-elökészités lehetséges feladatai a XXI. század kihivásai tükrében című munkájában megállapítja, hogy a hadszíntéren zajló ütközetek nemcsak a szemben álló katonai erőket terhelik, hanem az ütközetek jellegétől függően veszélyeztetik a polgári lakosságot, az anyagi és eszmei javakat is. A cikkben kiemeli az anyagi javak igénybevételéhez, valamint a lakosság veszélyeztetettségéhez, védelméhez kapcsolódóan a tervezés és az előkészítési feladatok fontosságát. Törekedni kell arra, hogy a harctevékenységek csak korlátozott területre terjedjenek annak érdekében, hogy minél kevésbé veszélyeztessék a lakosságot és az anyagi javakat, valamint a védelmi erők hatékonyan végezhessék a feladatukat. Ezt az adott területet a hadszíntér-előkészítés feladatrendszerében előzetesen fel kell készíteni a várható hatásokra. ${ }^{5}$

Muhoray Árpád A polgári védelem helye a modern katasztrófavédelemben című cikkében megállapítja, hogy a fegyveres összeütközés időszakában a polgári védelem a lakosság és az anyagi javak védelmezésével és annak irányításával számolt, de a feladatok nem teljes körüek. Számolni kell olyan fontos feladatokkal is, mint a támadófegyverek alkalmazását követő helyzetben a kárterület felderítése, a mentés, elsősegélynyújtás, a fertőtlenítés, mentesítés az ideiglenes helyreállítás és az átmeneti elhelyezés és ellátás megszervezése. ${ }^{6}$

A cikk témájának időszerűségét bizonyítja, hogy az elmúlt időszakban a polgári védelem feladatrendszerének vizsgálata és korszerűsítése nem foglalkozott súlyának megfelelően a fegyveres összeütközés időszakában végrehajtandó feladatokkal és azok logisztikai hátterével, illetve a biztonsági környezet változása, mint például a nemzetközi migráció, a szomszédos országban zajló fegyveres összeütközés felértékeli a katonai, valamint a kapcsolódó polgári védelmi képességek meglétét. A cikkben bemutatom a fegyveres összeütközés legfontosabb polgári védelmi feladatait, megvizsgálom, hogy a jelenlegi jogszabályi háttér megfelelően rögzíti-e a szervezet háborús feladatrendszerét, továbbá ismertetem a háborús védelmi tervek és a szakmai eljárásrendek kidolgozásának jelenlegi helyzetét.

\footnotetext{
LAPOS 1988, 2.

GYÖRÖK 2015, 59.

MUHORAY 2017, 191.
} 


\section{A polgári védelem szervezeti és feladatrendszerének változása az alaprendeltetés és a jogi szabályozás szemszögéből}

A polgári védelem szervezetének és feladatrendszerének változásai legjobban azok rövid történeti áttekintésével mutathatók be. A vizsgálatomat három időszakra végeztem el, a szervezeti, a feladat- és jogszabályi változásokat, valamint azok alapvető jellemzőit táblázatos formában mutatom be.

\section{A légoltalom megalakulásától 1972-ig terjedő időszak föbb jellemzői}

A következőkben áttekintem a polgári védelem szervezeti és feladatrendszerében történő változásait a jogelőd szervezetek megalakulásától 1972-ig.

1. táblázat. A megalakulástól 1972-ig terjedő időszak polgári védelemmel összefüggő főbb szervezeti és feladatrendszer változások és azok jellemzői

\begin{tabular}{|c|c|c|}
\hline Dátum & $\begin{array}{c}\text { Polgári védelem szervezeti és feladatrendszerének jog- } \\
\text { szabályi változásai }\end{array}$ & $\begin{array}{l}\text { Az alaprendeltetés változásának föbb } \\
\text { jellemzői }\end{array}$ \\
\hline 1917 & $\begin{array}{c}\text { Megalakul a „légi figyelő és riasztó szolgálat”, a magyar } \\
\text { légoltalom elődje. }\end{array}$ & \multirow{2}{*}{$\begin{array}{l}\text { Célja: a háborús légitámadások elleni védelem } \\
\text { kiépitése, pusztításainak csökkentése. }\end{array}$} \\
\hline 1935 & Hatósági Légoltalom7 felállítása. & \\
\hline 1937 & $\begin{array}{l}\text { Légoltalmi Liga megalakulása mint társadalmi (önkéntes) } \\
\text { szervezet. }\end{array}$ & $\begin{array}{c}\text { Szervezte a mentést, a kárfelszámolást, a sérültek } \\
\text { ellátását, az elsődleges helyreállítást, részt vett } \\
\text { a tüzek oltásában. }\end{array}$ \\
\hline 1949 & Állami légoltalom szervezete. & Belügyi irányitás alá kerül mint fegyveres testület. \\
\hline $\begin{array}{l}1951 . \\
\text { május }\end{array}$ & $\begin{array}{l}\text { Központi Légoltalmi Zászlóalj (továbbiakban: KLZ) } \\
\text { felállitása. }\end{array}$ & $\begin{array}{c}\text { Elsődleges feladata az ország területének löszer- } \\
\text { és bombamentesitése. }\end{array}$ \\
\hline 1960 & Légoltalom Országos Törzsparancsnokság felállítása. & $\begin{array}{l}\text { Feladatában megjelenik a honvédelemröl szóló } \\
\text { 1960. évi IV. törvény alapján a segitségnyújtási } \\
\text { kötelezettség elemi csapások esetére. } \\
\text { [3.§ (2) bekezdés] }\end{array}$ \\
\hline \multirow{2}{*}{$\begin{array}{c}1962 . \\
\text { november } 1 .\end{array}$} & $\begin{array}{l}\text { KLZ honvédelmi irányítás alá helyezése, névváltozás: } \\
\text { polgári védelem. }\end{array}$ & \multirow{3}{*}{$\begin{array}{c}\text { Kubai rakétaválságból „következő” esetleges } \\
\text { atomháborús veszély megjelenése. } \\
\text { Elsődleges feladat nukleáris fegyverek elleni } \\
\text { védelem. }\end{array}$} \\
\hline & $\begin{array}{c}\text { Polgári védelem }{ }^{8} \\
\text { (HM Polgári Védelem Országos Parancsnoksága). }\end{array}$ & \\
\hline $\begin{array}{c}1972 . \\
\text { január } 1 .\end{array}$ & Hátországvédelmi Alakulatok Parancsnoksága ${ }^{9}$ felállítása. & \\
\hline
\end{tabular}

Forrás: a szerző szerkesztése

1935. évi XII. törvény a légvédelemröl, 15/1936. sz. honvédelmi miniszteri rendelet alapján.

8 Az Elnöki Tanács 1964. évi 1. sz. törvényerejű rendelete a légoltalom kifejezés helyett a polgári védelem szóösszetétel használatát rendelte el.

9 Feladatait a 2041/1974. (XII. 11.) számú MT határozat a polgári védelemről, és az 1976. évi honvédelmi törvény szabályozta. 
A vizsgált időszakban a polgári védelem háborús feladatrendszere volt a meghatározó, elsődlegességet képeztek, alapvetően honvédelmi irányítás mellett, a háborús felkészülési feladatok. Ebben az időszakban a hátország védelme előtérbe helyezte a lakosság védelmének megszervezését, ugyanakkor 1960-tól jelen van az elemi csapások elleni védekezés kötelezettsége is.

\section{2-1990-ig terjedő időszak főbb jellemzői}

Az 1972 utáni, majd a kétpólusú világrend 1990-es években történő felbomlását követő időszak polgári védelmének társadalmi elismertsége ellentmondásosan alakult, a szervezet szükségessége is többször megkérdőjeleződött. A 2. táblázatban áttekintem a 1972-1990 közötti időszak föbb eseményeit.

2. táblázat. Az 1972-1990 közötti időszak polgári védelemmel összefüggő főbb események és azok jellemzői

\begin{tabular}{|c|c|c|}
\hline Dátum & $\begin{array}{l}\text { Polgári védelem szervezeti, feladatrendszerének } \\
\text { jogszabályi változásai }\end{array}$ & Az alaprendeltetés változásának föbb jellemzői \\
\hline $\begin{array}{c}1972 . \\
\text { január } 1 .\end{array}$ & $\begin{array}{l}\text { Hátországvédelmi Alakulatok Parancsnoksága }{ }^{10} \\
\text { felállítása }\end{array}$ & Feladata a nukleáris fegyverek elleni védelem. \\
\hline 1974 & 2041/1974. (XII. 11.) számú MT határozat. & $\begin{array}{l}\text { Meghatározza a polgári védelem háborús } \\
\text { feladatrendszerét. }{ }^{11}\end{array}$ \\
\hline 1976 & 1976. évi I. törvény a honvédelemröl. ${ }^{12}$ & $\begin{array}{l}\text { Az új honvédelmi törvény a polgári védelmi kötelezett- } \\
\text { ségeket az elemi csapások és más rendkivüli esemé- } \\
\text { nyek időszakára is kiterjesztette. }\end{array}$ \\
\hline 1986 & $\begin{array}{l}\text { A csernobili atomerőmű-katasztrófa } \\
\text { utáni átszervezési kezdeményezések. }\end{array}$ & $\begin{array}{l}\text { Az atomerőművi baleset után kialakult helyzet meg- } \\
\text { változtatta a polgári védelem általános megítélését, } \\
\text { egy határokon átívelő válsághelyzet esetén. Felvető- } \\
\text { dött - a baleseten túlmutató - egységes katasztrófa- } \\
\text { védelmi rendszer elméleti megalapozásának, szervezeti } \\
\text { és irányítási rendszere létrehozásának szükségessége. }\end{array}$ \\
\hline 1989 & $\begin{array}{c}\text { Az 1989. évi 20. törvényerejü rendeletben kihirdet- } \\
\text { ték az 1949. augusztus } 12 \text {-én kötött Egyezmények I. } \\
\text { és II. Kiegészítő Jegyzőkönyveket. }{ }^{13}\end{array}$ & $\begin{array}{l}\text { A Jegyzökönyv szerint: a polgári védelem fogalma alatt } \\
\text { értendő minden olyan humanitárius feladat, amelynek } \\
\text { célja, hogy védelmet nyújtson a polgári lakosságnak az el- } \\
\text { lenségeskedés, a háborús cselekmények, illetöleg kataszt- } \\
\text { rófák ellen és segitsen azok közvetlen hatásainak leküzdé- } \\
\text { sében, illetve a túlélés feltételeinek biztositásában. }\end{array}$ \\
\hline
\end{tabular}

10 Feladatait a 2041/1974. (XII. 11.) számú MT határozat a polgári védelemröl, és az 1976. évi honvédelmi törvény szabályozta.

11 2041/1974. (XII. 11.) számú MT határozat 2. pont: „A polgári védelem - a honvédelem részeként - az élet és az anyagi javak támadófegyverek hatásai elleni védelmét, valamint az elemi csapások, az ipari és egyéb katasztrófák elhárításában való közreműködést szolgáló intézkedések, továbbá az azok alapján állami, társadalmi és egyéni erővel megvalósuló védekezés rendszere."

12 A törvény a honvédelmi miniszter irányítása alá helyezte a korábbi légoltalmat (polgári védelmet), és a törvény végrehajtására kiadott 6/1976. (III. 31.) MT rendelet, valamint az annak végrehajtását szabályozó 2/1976. (VI. 17.) számú honvédelmi miniszteri rendelet határozta meg a részletszabályokat.

13 Az aláírók kötelezettséget vállaltak, hogy a jegyzőkönyvekben foglaltakat illesztik a nemzeti jogrendjükbe. A nemzeti jogrendbe illesztés a polgári védelemről szóló 1996. évi XXXVII. törvénnyel történt meg. 


\begin{tabular}{|c|c|c|}
\hline Dátum & $\begin{array}{l}\text { Polgári védelem szervezeti, feladatrendszerének } \\
\text { jogszabályi változásai }\end{array}$ & Az alaprendeltetés változásának föbb jellemzői \\
\hline 1989 & $\begin{array}{l}\text { 3344/1989. sz. } \\
\text { MT határozat. }\end{array}$ & $\begin{array}{c}\text { A nemzetközi jogi szabályozások hazai integrá- } \\
\text { lása, illetve a rendszerváltás utáni demokratikus } \\
\text { államberendezkedéshez való illeszkedés érdekében } \\
\text { a 3344/1989. sz. MT határozat alapján a polgári } \\
\text { védelem irányítása a Belügyminisztérium hatáskörébe } \\
\text { került. }\end{array}$ \\
\hline 1989 & $\begin{array}{c}\text { A rendszerváltást megelőző új alkotmányozási } \\
\text { időszak. }\end{array}$ & $\begin{array}{l}\text { Az 1989. október } 23 \text {-tól az 1989. évi XXXI. törvény } \\
\text { iktatta be az alkotmány új tartalmú } 35 \text {. §-t - a veszély- } \\
\text { helyzet fogalmát és az intézkedéseket. }\end{array}$ \\
\hline
\end{tabular}

Forrás: a szerző szerkesztése

A fenti időszakra vonatkozó főbb megállapítások:

- A polgári védelemnek 1972 után egyszerre kellett megfelelnie a háborús fenyegetettség és a békeidős feladatként jelentkező katasztrófák elleni védekezés feladatainak. Ezt az 1976. évi új honvédelmi törvény megerősítette.

- 1986. április 26-án bekövetkező csernobili atomerőmü-katasztrófa után megváltozott a polgári védelem általános megítélése. Felvetődött - a baleseten túlmutató - egységes katasztrófavédelmi rendszer elméleti megalapozásának, szervezeti és irányítási rendszere létrehozásának szükségessége.

- Általánosságban elmondható, hogy a polgári védelem rendszere, az akkori nemzetközi követelményeknek és a hazai igényeknek megfelelően a Magyar Népköztársaság Honvédelmi Alapelveihez és az Alkotmányához - 1949. évi XX. törvény - igazodva felkészült egy esetleges alkalmazás során a lakosság és anyagi javak védelmére. Rendelkezett a működését biztosító jogszabályokkal, illetve vezetési és irányítási rendszere illeszkedett az akkori védelmi igazgatás rendszeréhez.

\section{Az 1990 utáni időszak föbb jellemzöi}

A rendszerváltást követően, az 1990 előtti háborús fenyegetettség csökkenése miatt hazánkban is megkezdődött a haderő átalakítása, amely komoly védelmiképesség-csökkenést eredményezett. Sajnos a polgári védelem is jelentős képességvesztésen esik át, a katasztrófák elleni védekezéshez szükséges képességek kialakítása viszont csak lassú ütemben valósult meg. A polgári védelem területével összefüggő változásokat a 3. táblázat tartalmazza. 
3. táblázat. Az 1990 utáni időszak polgári védelemmel összefüggő főbb események és azok jellemzői

\begin{tabular}{|c|c|c|}
\hline Dátum & $\begin{array}{l}\text { Polgári védelem szervezeti, feladatrendszer- } \\
\text { ének jogszabályi változásai }\end{array}$ & A változtatások föbb jellemzői \\
\hline \multirow[t]{2}{*}{1990} & $\begin{array}{l}\text { 3344/1989. sz. } \\
\text { MT határozat alapján. }\end{array}$ & $\begin{array}{l}\text { A polgári védelem feladata és } \\
\text { szervezete 1990-ben a Honvédelmi Minisztériumtól átkerült } \\
\text { a Belügyminisztérium irányitása alá. }{ }^{14}\end{array}$ \\
\hline & $\begin{array}{c}\text { 2041/1974. (XII. 11.) } \\
\text { Számú MT határozat hatályon kívül helyezése. }\end{array}$ & A polgári védelem jogi státusza „rendezetlenné vált”. \\
\hline 1991 & $\begin{array}{l}\text { A helyi önkormányzatok és szerveik, a köztár- } \\
\text { sasági megbízottak, valamint egyes centrális } \\
\text { alárendeltségű szervek feladat- és hatáskörei- } \\
\text { ről szóló 1991. évi XX. törvény. }\end{array}$ & $\begin{array}{l}\text { 17. § (1) A köztársasági megbízott és a polgármester, a föpolgármes- } \\
\text { ter polgári védelmi feladatait a Korm. rendeletben állapítja meg. }\end{array}$ \\
\hline 1993 & $\begin{array}{l}\text { Magyar Köztársaság honvédelmi alapelveiröl } \\
\text { szóló 27/1993. (IV. 23.) OGY határozat.. }\end{array}$ & $\begin{array}{l}\text { Az OGY határozat 23. pontja alapján a polgári védelemnek } \\
\text { kettős feladatrendszere van. Békeidőben a katasztrófavédelmi } \\
\text { feladatok, mig „az országot ért fegyveres támadás esetén a pol- } \\
\text { gári védelem feladata a polgári lakosság és objektumok ellen } \\
\text { irányuló csapások, rombolások okozta károk következményeinek } \\
\text { felszámolása, a lakosság életének és anyagi javainak megóvása” } \\
\text { feladatok kerülnek előtérbe. }\end{array}$ \\
\hline 1993 & 1993. évi CX. törvény a honvédelemről. & $\begin{array}{c}\text { Az Országgyülés a honvédelmi miniszter felelösségi körébe utalta } \\
\text { a honvédelemmel kapcsolatos teljes irányítást. }{ }^{16}\end{array}$ \\
\hline \multirow[b]{2}{*}{1995} & $\begin{array}{l}\text { Tüz-és Polgári Védelmi Országos } \\
\text { Parancsnokság felállítása. }{ }^{17}\end{array}$ & $\begin{array}{l}\text { Az integrált szervezet létrehozását az Alkotmánybíróság 18/1995. } \\
\text { (III. 18.) határozata akadályozta meg. }\end{array}$ \\
\hline & $\begin{array}{l}\text { A települések } \\
\text { polgári védelmi besorolásának szabá- } \\
\text { lyairól és a védelmi követelményekről szóló } \\
\text { 114/1995. (IX. 27.) Korm. rendelet. }\end{array}$ & $\begin{array}{c}\text { Célja: az ország katasztrófaveszélyeztetettségének felmérése } \\
\text { és kategóriákba történő } \\
\text { besorolása. }\end{array}$ \\
\hline 1996 & $\begin{array}{l}\text { Polgári védelmi törvény } \\
\text { elfogadásával } \\
\text { a katasztrófaelhárítás } \\
\text { közremüködésből } \\
\text { feladattá emelkedett. } \\
\text { Cél: új felfogású, válságkezelésre orientált pol- } \\
\text { gári védelem megteremtése. }\end{array}$ & $\begin{array}{l}\text { A jogszabály kimondja, hogy a polgári védelem a honvédelem } \\
\text { rendszerében megvalósuló szervezet-, feladat- és intézkedési } \\
\text { rendszer. Célja a fegyveres összeütközés, a katasztrófa és más } \\
\text { veszélyhelyzet esetén a lakosság életének megóvása, az életben } \\
\text { maradás feltételeinek biztosítása, az állampolgárok felkészítése } \\
\text { az azok hatásainak leküzdése és a túlélés feltételeinek } \\
\text { megteremtése érdekében. }\end{array}$ \\
\hline 1998 & $\begin{array}{c}\text { A Magyar Köztársaság biztonság- és védelem- } \\
\text { politikai alapelveiröl szóló 94/1998. (XII. 29.) } \\
\text { OGY határozat. }{ }^{18}\end{array}$ & $\begin{array}{l}\text { A NATO-csatlakozási folyamattal összefüggésben a védelmi } \\
\text { igazgatási rendszer, a polgári veszélyhelyzeti tervezés szervezeti } \\
\text { rendszerének kialakitása. }\end{array}$ \\
\hline
\end{tabular}

14 A Minisztertanács MT 3344/1989. számú határozat alapján.

15 A határozatot az Országgyúlés az 1993. április 14-i ülésnapján fogadta el.

16 A honvédelemről szóló 1993. évi CX. törvény 9. § (1) szerint: „A honvédelmi miniszter a Kormánynak az ország honvédelmi feladatainak végrehajtásáért felelős szakminisztere." 1993. évi CX. törvény 10. §-a alapján a honvédelmi miniszter együtt kell, hogy müködjön más ágazati miniszterekkel - „a katonai és a polgári védelem szempontjából fontos létesítmények elhelyezésében, továbbá az egészségügyi, a közlekedési, a hírközlési hálózat, valamint a légi, a vegyi és sugárfigyelő jelző- és riasztási rendszer működőképességének - a kiépítettségétől elvárható módon történő - biztosításában."

17 Az Alkotmánybíróság 18/1995. (III. 18.) határozatában megállapította, hogy a tủzvédelem és a polgári védelem központi irányításáról szóló 85/1993. (VI. 1.) Korm. rendelet, a polgári védelemről szóló 15/1992. (I. 27.) Korm. rendelet, az ennek végrehajtásáról rendelkező 7/1992. (V. 19.) BM rendelet, a honvédelemről szóló már hatályon kívül helyezett 1976. évi I. tv. végrehajtása tárgyában megjelent 6/1976. (III. 31.) MT rendelet alkotmányellenes. Az Alkotmánybíróság az emlitett rendeletek megsemmisitésére irányuló eljárást 1995. december 31-igfelfüggesztette.

18 94/1998. (XII. 29.) OGY határozat 13. pont 2. bekezdés - „A Magyar Köztársaság a honvédelmet az állampolgárok közös felelősségvállalásán alapuló nemzeti ügynek tekinti. A honvédelem rendszere az Észak-atlanti Szerződésből fakadó jogok és kötelezettségek egységére, az ország és a Szövetség védelmi igényeit tudatosan elfogadó 


\begin{tabular}{|c|c|c|}
\hline Dátum & $\begin{array}{c}\text { Polgári védelem szervezeti, feladatrendszer- } \\
\text { ének jogszabályi változásai }\end{array}$ & A változtatások föbb jellemzői \\
\hline 1999 & $\begin{array}{l}\text { A katasztrófák elleni védekezés irányításáról, } \\
\text { szervezetéről és a veszélyes anyagokkal kap- } \\
\text { csolatos súlyos balesetek elleni védekezésről } \\
\text { szóló 1999. évi LXXIV. törvény. } \\
\text { Országos Katasztrófavédelmi Főigazgatóság } \\
\text { létrehozása. } \\
\text { Azz Észak-atlanti Szerződés Szervezetébe } \\
\text { (NATO-ba) való belépés és katasztrófavédelmi } \\
\text { képviselet. }\end{array}$ & $\begin{array}{l}\text { 2000. január 1-töl megvalósult a mủveleti integrációja a tüzoltó- } \\
\text { ságnak és a polgári védelemnek. } \\
\text { A NATO Polgári Veszélyhelyzeti Kezelési tevékenységében } \\
\text { a polgári veszélyhelyzet tervezés NATO Miniszteri Irányelvekböl } \\
\text { származó nemzeti feladatokról szóló } 2010 / 2002 \text {. (I. 25.) Korm. } \\
\text { határozat alapján a belügyminisztérium vesz részt. }\end{array}$ \\
\hline 2004 & $\begin{array}{l}\text { A honvédelemröl és a Magyar Honvédségről } \\
\text { szóló 2004. évi. CV. törvény elfogadása. }\end{array}$ & \\
\hline 2011 & $\begin{array}{l}\text { Alkotmányozás: Alaptörvény és új honvédelmi } \\
\text { és katasztrófavédelmi szabályozás elfogadása. }\end{array}$ & $\begin{array}{l}\text { 2012. január 1-től új katasztrófavédelmi szabályozás } \\
\text { hatálybalépése, az Országos Katasztrófavédelmi Főigazgatóság } \\
\text { átszervezése. }\end{array}$ \\
\hline 2012 & $\begin{array}{l}\text { Magyarország Nemzeti Katonai Stratégiájáról } \\
\text { szóló 1656/2012. (XII. 20.) Korm. határozat. }\end{array}$ & $\begin{array}{l}\text { Korm. határozat 9. pontja kimondja, hogy hazánk „egyetlen álla- } \\
\text { mot sem tekint ellenségének”, illetve a 10. pontban meghatároz- } \\
\text { za, hogy hazánk „ellen irányuló agresszió esetén - összhangban } \\
\text { az ENSZ Alapokmányának 51. cikkében foglaltakkal - Magyar- } \\
\text { ország minden szükséges lépést megtesz függetlenségének, } \\
\text { területének, légterének, lakosságának és anyagi javainak védelme } \\
\text { érdekében”. Mivel nincs ellenségképünk, ugyanakkor fenntartjuk } \\
\text { magunknak a jogot az önvédelemre, ezért az erre vonatkozó } \\
\text { fegyveres védelmi tervhez igazodó háborús polgári védelmi terv } \\
\text { megléte elengedhetetlen kell hogy legyen. }\end{array}$ \\
\hline
\end{tabular}

Forrás: a szerző szerkesztése

Az 1990-es évektől kezdődően jelentős változások következtek be nemzetközi szinten és hazánkban egyaránt. A biztonsági környezet és katonai stratégiák változása, a genfi egyezmények tartalmának módosulásai, a NATO-hoz való csatlakozás stb. hazánkban is átalakította a polgári védelemmel szembeni elvárásokat, ezáltal megváltozott a szervezet alaprendeltetésén belül a különböző feladatrendszerek prioritása is. A hangsúly áttevődött a katasztrófák elleni védekezés feladatainak irányába, a háborús felkészülés pedig részben háttérbe szorult. Ezáltal a polgári védelem kettős feladatrendszerének végrehajtására való képesség eltolódott a katasztrófák elleni védekezés irányába.

\section{A 3. táblázatban jelzett időszakra vonatkozó főbb megállapítások:}

- 2000. január 1-jén hatályba lépett az 1999. évi LXXIV. törvény a katasztrófák elleni védekezés irányításáról, szervezetéről és a veszélyes anyagokkal kapcsolatos súlyos balesetek elleni védekezésről, amelynek alapján végrehajtásra került a polgári védelem és az állami

polgárok önbecsülésére és felelősségére, a fegyveres erők és a védelem anyagi szükségleteit kielégíteni képes gazdaságra, a védelemre felkészült államszervezetre, a védelem katonai feladatait ellátni képes fegyveres erőkre, a fegyveres erők demokratikus és polgári irányítására és ellenőrzésére, a lakosság és az anyagi javak megóvását szolgáló polgári védelemre, valamint a magyar társadalom legszélesebb rétegeinek támogatására épül." 
tủzoltóság integrációja, és létrejött a Belügyminisztérium Országos Katasztrófavédelmi Főigazgatóság. ${ }^{19}$

- A polgári védelem első komolyabb felülvizsgálata az integrációt követően 2003-ban történt meg. ennek tapasztalatai alapján, valamint a közigazgatás átalakításával összhangban, a katasztrófavédelem szervezetrendszere régió/kistérség szerinti átalakításának lehetőségéről a BM OKF által több előterjesztés is készült. Ezenkívül a BM OKF veszélyhelyzetkezelési főigazgató-helyettesi előterjesztésekben több előremutató javaslat lett megfogalmazva, mint például a polgári védelmi felkészítésről szóló 13/1998. (III. 6.) BM rendelet felülvizsgálata, illetve az önkéntes haderő miatt a készülő új honvédelmi törvény és a polgári védelmi jogszabályi szabályozás harmonizációja.

- A honvédelemröl és a Magyar Honvédségről szóló 2004. évi CV. törvény 50. § (1) bekezdésében a kormány feladatkörébe utalta - az ország védelmi felkészültségének biztosítása céljából - „a nemzetgazdaság felkészítésével kapcsolatos követelményeket, az ország védelmi célú tartalékait, hadiipari kapacitását, valamint az infrastruktúra honvédelmi célú felkészítésének és fejlesztésének állami feladatait, dönt a gazdaság mozgósításáról, és meghatározza a polgári védelmi felkészítés feladatait". ${ }^{20}$

- 2010-ben politikai és szakmai állásfoglalás született arról, hogy továbbra is foglalkozni kell a fegyveres konfliktusok esetére tervezett lakossági oltalmazással, ezért felül kell vizsgálni az általános polgári védelmi tervrendszert, elodázhatatlan a polgári védelem technikai fejlesztése. Döntés született arról is, hogy felül kell vizsgálni a logisztikai készleteket és a kiszállítások rendjét, valamint korszerüsíteni kell, reálisveszély-alapú megközelítéssel, a települések polgári védelmi veszélyeztetettségi besorolását, hozzáigazítva a veszélyhelyzeti terveket és a polgári védelmi szervezetek diszlokációját. ${ }^{21}$

- 2011. évben új Alaptörvényt, ${ }^{22}$ honvédelmi ${ }^{23}$ és katasztrófavédelmi törvényt fogadtak el. Hazánk egységes védelme szempontjából a jogszabályok kimondják, hogy a polgári

19 Muhoray 2017, 194. Az újonnan létrehozott szervezet, a szakirányítási feladatokon túl kiemelt hatósági- és veszélyhelyzetkezelési jogköröket kapott. A polgári védelem az új szervezetben a polgári védelmi feladatok országos irányításáért négy főosztály: a Polgári Veszélyhelyzet kezelési Főosztály, a Minősített időszaki Tervezési Főosztály, részben a Mentésszervezési Főosztály, valamint a Koordinációs Főosztály foglalkozott, ez utóbbi a lakosságfelkészítéssel és az újjáépítéssel. A területi szintű irányítást a polgári veszélyhelyzetkezelési osztály, illetve a mentésszervezési osztály végezte, helyi szinten polgári védelmi kirendeltségeket és az alárendeltségükben polgári védelmi irodákat hoztak létre.

20 A honvédelemről és a Magyar Honvédségről szóló 2004. évi CV. törvény 50. § (1) d) és e) pont. Hatályon kívül helyezte: 2011. évi CXIII. törvény 82. § (2) c). Hatálytalan: 2012. I. 1-től.

21 Muhoray 2017, 197.

22 Magyarország Alaptörvénye önálló fejezetben, a 48-54. cikkekben szabályozza a különleges jogrendet, megkülönböztetve a rendkívüli állapot, a szükségállapot, a megelőző védelmi helyzet, a terrorveszélyhelyzet, a váratlan támadás és a veszélyhelyzet időszakokat. A háborús polgári védelmi feladatok a rendkívüli állapot, a szükségállapot, a megelőző védelmi helyzet és a váratlan támadás időszakaiban kell hogy végrehajtásra kerüljenek. Az Alaptörvénye a XXXI. cikk (5) pontjában az alábbiakat határozza meg: „Magyarországi lakóhellyel rendelkező, nagykorú magyar állampolgárok számára honvédelmi és katasztrófavédelmi feladatok ellátása érdekében - sarkalatos törvényben meghatározottak szerint - polgári védelmi kötelezettség írható elő."

23 A hatályos a Magyar Honvédségről, valamint a különleges jogrendben bevezethető intézkedésekről 2011. évi CXIII. törvény (továbbiakban: Hvt.) 22. § (1) pontja fenntartja ezt a felelősséget, miszerint: „A honvédelemért felelős miniszter a Kormánynak az ország honvédelmi, és a válságkezelés katonai feladatai végrehajtásáért, valamint a Honvédség irányításáért és vezetéséért felelős tagja." 
védelem része Magyarország honvédelmi rendszerének, alapvetően békeidős - katasztrófavédelmi és háborús időszaki feladatrendszerrel rendelkezik. Továbbá, Magyarország Nemzeti Katonai Stratégiájáról szóló 1656/2012. (XII. 20.) Korm. határozat (továbbiakban: NKS) alapján a polgári védelmi feladatok védelmi műveleti időszakban végrehajtandó feladatainak tervezése, szervezése, begyakorlása alapvetően szükséges a tényleges védelem megvalósítása érdekében.

- NKS deklarálja, hogy nincs ellenségképünk, de fenntartjuk magunknak a jogot az önvédelemre, ezért elengedhetetlen, az ország fegyveres védelmi tervéhez ${ }^{24}$ igazodó, háborús polgári védelmi tervek kidolgozása és megléte.

- A katonai tervekkel összhangban végrehajtandó polgári védelmi feladatokról tényleges jogszabályi hivatkozás a Hvt. 11. §-ban található az alábbiak szerint: „(6) A fegyveres összeütközések időszakában végrehajtandó polgári védelmi feladatokkal összefüggő felkészítésre, végrehajtásra, valamint készletképzésre vonatkozó részletes követelményeket az ország fegyveres védelmi terve tartalmazza."

- A háborús polgári védelmi feladatok végrehajtása érdekében a Hvt. végrehajtási rendelete $^{25}$ a katasztrófák elleni védekezésért felelős miniszter részére határozza meg a háborús polgári védelmi feladatokra történő felkészülési és a lakosság felkészítésének feladatait, a légiriasztással kapcsolatos feladatok végrehajtását, továbbá a honvédelmi felkészítés éves feladattervében szereplő, a fegyveres összeütközések időszakában végrehajtandó feladatokat.

- A 2012. január 1-jén hatályba lépett új jogszabályok alapján egy, a megelőzés kulcsfontosságát kifejezetten hangsúlyozó, új katasztrófavédelmi rendszert alakítottak ki, amelynek alaprendeltetése, hogy állami irányítás mellett egyszerre kell ellátnia békeidős és háborús feladatokat, az ehhez rendelt szervezetekkel, és folyamatosan fejlesztés alatt álló képességekkel. ${ }^{26}$

24 Az ország fegyveres védelmi tervéről - jellegéből következően - sok információ nem áll rendelkezésre. A kapcsolódó háborús polgári védelmi tervnek - fent nevezett hadműveleti követelmények alapján - ehhez igazodóan tartalmaznia kell azonban valós számvetések szerint az esetleges érintett lakosságra végrehajtandó feladatokat. A tervezéssel, illetve a tervek sajátosságaival a következő fejezetben foglalkozom.

25 290/2011. (XII. 22.) Korm. rendelet.

26 Muhoray 2017, 198. Az új típusú polgári védelem, az angol terminológiából ismert „civil protection” kifejezés jelentésének megfelelően, a nem háborús veszélyeztetettség szempontjából jelentkező lakosságvédelmi, felkészítési és megelőzési feladatokat látja el. A 2012-től hatályos új törvényi szabályozással összefüggésben Dr. Muhoray Árpád A polgári védelem helye a modern katasztrófavédelemben című munkájában leírta, hogy a 2012-től hatályos Kvt. a polgári védelemmel kapcsolatosan átvette a korábbi törvényi szabályzás zömét, kis változtatással. Megjelennek a törvényben a lakosság felkészítési, a polgári védelmi szervezetek létrehozási, a tájékoztatás, figyelmeztetés, riasztás, az egyéni védőeszközökkel ellátási és a kárterületi tevékenységek. Azúj törvény komoly változtatásokat léptetett életbe. Ilyen változtatás volt az óvóhelyi védelem helyett a védelmi célú építmények fenntartásának feladata, a lakosság kimenekítése, kitelepítése a befogadással, a létfenntartáshoz szükséges anyagi javak védelmének kiegészítése a kritikus infrastruktúrák védelmével, törölték az elsötétítést, fényálcázást [megjegyzés: a Hvt. 11. § (3) bekezdésében az elsötétítés szerepel], valamint a települések veszélyeztetettségének felmérése kiegészül annak a kockázatértékelésre való alapozásával, valamint a polgári védelmi tervezés, szervezés helyett pedig veszélyelhárítási-tervezés és szervezés feladata szerepel. 
Összességében megállapítható, hogy a polgári védelem és jogelődjeinek elsődleges feladata 1972-ig a háborús összeütközés elleni védelem volt. Ezt követően jelenik meg az úgynevezett kettős alaprendeltetés, vagyis háborús és a békeidős katasztrófák elleni védekezés feladatrendszere. Ennek a kettős feladatrendszernek ugyanarra az egységes szervezeti és erőforrásra kellett volna épülnie, de a politikai, a katonai és a biztonsági helyzet alakulásával a polgári védelem „létjogosultsága" eltolódott a háborús feladatrendszertől a békeidős feladatrendszer irányába.

\section{A polgári védelmi háborús és katasztrófavédelmi feladatainak összehasonlító csoportosítása}

A jelenleg hatályos Kvt. háborús polgári védelmi feladatokra vonatkozóan taxatív jogszabályi hivatkozást nem tartalmaz. A háborús polgári védelmi feladatokat a hatályos Hvt. 11. § (3) és a katasztrófavédelmi célú polgári védelmi feladatokat a hatályos Ktv. 52 . § bekezdése határozza meg. A 4. táblázatban - kiindulva a Hvt.-ben és a Kvt.-ben meghatározott feladatokból - összehasonlítottam a polgári védelem háborús és katasztrófavédelmi feladatait három funkcionális csoportosítás szerint: a lakosság és az anyagi javak megóvása, az infrastruktúrát érintő, valamint csak a fegyveres összeütközés (háborús) időszakában végrehajtandó a polgári védelmi alkalmazási műveleti feladatok.

A feladatok összehasonlító csoportosítása alapján megállapítható, hogy egy fegyveres öszszeütközés időszakában a lakosság fenyegetettségét továbbra is valós veszélyként kell kezelni és a védekezéssel összefüggő feladatok megjelennek, ha más elnevezéssel is, a katasztrófavédelmi feladatok között. A háborús feladatokat a jelenlegi szervezeti elemekkel és erőforrásokkal kell végrehajtani, mert külön háborús polgári védelmi szervezet nem létezik. Viszont a képességeket az akkori igényekhez és feladatokhoz, a veszélyeztetettségnek megfelelően, a rendelkezésre álló tervek alapján, a felkészülési időszakban ki kell alakítani. A lakosságvédelmi intézkedésekre ${ }^{27}$ való felkészülést már a hadszíntér-előkészítés feladatai között szerepeltetni kell, lehetőség szerint tervezési szinten és a védelmi terveket úgy kell összeállítani, hogy a várható veszélyeztetettségnek megfelelően minden magyar állampolgárt - lakóhelytől függetlenül - egyenlő és teljes értékű védelem illessen meg, valamint a tervezési szinten megjelenő feladatokhoz hozzá kell rendelni a szükséges erőforrásokat, logisztikai hátteret.

27 A végrehajtandó lakosságvédelmi intézkedések magukba foglalják a lakosság riasztását, az egyéni védőeszközellátást, a kitelepítést, a kimenekítést és a befogadás, kimenekítés feladatait. A Kat. Vhr. 32. § meghatározza a lakosság védelmének alapvető módszereit, amelyek a helyi és a távolsági védelem, az alábbiak szerint:

- „a helyi védelem az elzárkózás a veszélyeztető hatás elleni védelemre alkalmas, illetve alkalmassá tett helyen,

- a távolsági védelem a lakosság veszélyeztetett területről történő kimenekítése, illetve kitelepítése, valamint befogadóhelyen történő átmeneti jellegű elhelyezése". 
4. táblázat. A polgári védelmi feladatok funkcionális csoportosítása, összehasonlítása

\begin{tabular}{|c|c|c|}
\hline \multirow{7}{*}{ 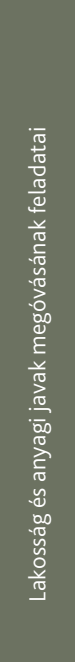 } & $\begin{array}{l}\text { A fegyveres összeütközések időszakában } \\
\text { végrehajtandó polgári védelmi feladatok }\end{array}$ & $\begin{array}{l}\text { A polgári védelem katasztrófavédelemmel } \\
\text { kapcsolatos feladatai }\end{array}$ \\
\hline & - riasztás (hadműveleti) & - tájékoztatás, figyelmeztetés, riasztás \\
\hline & - kiürítés és befogadás & \multirow{2}{*}{$\begin{array}{l}\text { - a lakosság kimenekítése, kitelepítése és befoga- } \\
\text { dása }\end{array}$} \\
\hline & - szükségelszállásolás és ellátás & \\
\hline & $\begin{array}{l}\text { - veszélyes vagy szennyezett területek megjelölése } \\
\text { - vegyi- és sugárfelderítés, -mentesítés, fertötlení- } \\
\text { - a halottakkal kapcsolatos halaszthatatlan járvány- } \\
\text { és közegészségügyi, továbbá kegyeleti és egyéb } \\
\text { adminisztrációs feladatok ellátása } \\
\text { - elsősegélynyújtás, lelki gondozás }\end{array}$ & $\begin{array}{l}\text { - a kárterület felderitése, a mentés, az elsősegély- } \\
\text { nyújtás, a mentesités és a fertőtlenítés, és az ezek- } \\
\text { kel összefüggő ideiglenes helyreállítás, továbbá } \\
\text { a halálos áldozatokkal kapcsolatos halaszthatat- } \\
\text { lan intézkedések } \\
\text { - } \text { az egyéni védőeszközökkel történő ellátás }\end{array}$ \\
\hline & \multirow[t]{2}{*}{$\begin{array}{l}\text { - a lakosság és a lakosság ellátásához szükséges } \\
\text { nemzetgazdasági javak mentése }\end{array}$} & $\begin{array}{l}\text { - közremüködés a kulturális örökség védett elemei- } \\
\text { nek megóvásában (védelmében) }\end{array}$ \\
\hline & & $\begin{array}{l}\text { - közremüködés a vizek kártételei elleni védekezés } \\
\text { külön jogszabályban meghatározott feladatainak } \\
\text { ellátásában }\end{array}$ \\
\hline \multirow{4}{*}{ 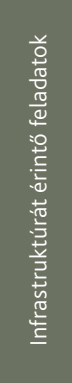 } & - óvóhelyek létesítése, fenntartása, müködtetése & - védelmi célú építmények fenntartása \\
\hline & - tüzoltás & - (közremüködés) tűzoltásban \\
\hline & $\begin{array}{l}\text { - a létfontosságú közmüvek működési feltételeinek } \\
\text { gyors helyreállítása }\end{array}$ & $\begin{array}{l}\text { - gondoskodás a létfenntartáshoz szükséges anyagi } \\
\text { javak (különösen víz-, élelmiszer-, takarmány- } \\
\text { és gyógyszerkészletek, állatállomány) és a kritikus } \\
\text { infrastruktúrák védelméről }\end{array}$ \\
\hline & $\begin{array}{l}\text { - közremüködés a lakosság túléléséhez szükséges } \\
\text { nélkülözhetetlen létesítmények müködőképessé- } \\
\text { gének fenntartásában }\end{array}$ & $\begin{array}{l}\text { - közszolgáltatás ellátásának kiesésekor az emberi } \\
\text { életben, egészségben és az anyagi javakban esett } \\
\text { kár megelőzése céljából a közszolgáltatás ideigle- } \\
\text { nes ellátásáról történő gondoskodás }\end{array}$ \\
\hline 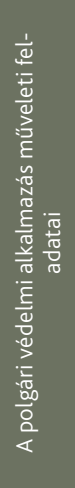 & $\begin{array}{l}\text { - a fegyveres összeütközések idöszakában végre kell } \\
\text { hajtani mindazon polgári védelmi feladatokat, } \\
\text { amelyek a harc megvívása során az adott hely- } \\
\text { zetben jelentkeznek, valamint a szövetséges erök } \\
\text { befogadásával kapcsolatosak } \\
\text { - az ismert adatok és paraméterek alapján el kell ké- } \\
\text { szíteni a szükséges müveleti, szervezési, valamint } \\
\text { a végrehajtás anyagi-technikai biztosítási terveit }\end{array}$ & $\begin{array}{l}\text { - a lakosság felkészítése a védekezés során irányadó } \\
\text { magatartási szabályokra } \\
\text { - a települések kockázatértékelésen alapuló veszé- } \\
\text { lyeztetettségének felmérése } \\
\text { - a veszélyelhárítási tervezés, szervezés } \\
\text { - a polgári védelmi szervezetek létrehozása és felké- } \\
\text { szítése, valamint a működéshez szükséges anyagi } \\
\text { készletek biztosítása, } \\
\text { - } \text { (közremüködés) a nemzetközi szerződésekből } \\
\text { adódó tájékoztatás és kölcsönös segítségnyújtás } \\
\text { feladatainak ellátásában } \\
\text { - közreműködés a menedékjogról szóló törvény } \\
\text { hatálya alá tartozó személy elhelyezésében és el- } \\
\text { látásában }\end{array}$ \\
\hline 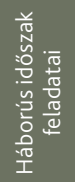 & $\begin{array}{l}\text { - elsötétítési rendszabályok kidolgozása, alkalmazása } \\
\text { területek rendjének helyreállítására és fenn- } \\
\text { tartására }\end{array}$ & \\
\hline
\end{tabular}

Forrás: a szerző szerkesztése 
A következőkben áttekintem a polgári védelem háborús feladatrendszere megtervezésével és végrehajtásával kapcsolatos elveket, követelményeket.

\section{A védelmi és a veszélyelhárítási tervezés formái, végrehajtásának általános jellemzői}

A második világháború utáni hidegháborús időszak katonai stratégiáit és célkitűzéseit alapvetően meghatározták azok a politikai szándékok és megállapodások, amelyek ebben az időszakban születtek. A két világrendszer katonai szembenállásának alapja az atomfegyver és a korlátlan fegyverkezés volt. Az „elrettentés” stratégiáját a győztesek mindegyike a maga érdeke szerint értelmezte és a saját céljai elérése érdekében alkalmazta. Ehhez mindegyik fél felhasználta a saját, rendelkezésére álló teljes politikai, gazdasági és katonai eszköztárát. Ilyen „eszköz" volt az atom- és ürfegyverkezés, a hátország szükség szerinti támadására alkalmas fegyverek fejlesztése, a szembenálló katonai tömbök egyre erőltetettebb hagyományos fegyverekre épülő tömeghadsereg fenntartása, a gazdaságok hadigazdasági „átállíthatóságának” megvalósítása. Véleményem szerint ez a gondolkodás teljesen „közgazdaság-idegen”, mert rendkívül költséges fejlesztéseket és védelmi tervezési rendszereket működtettek. Ezért, a két világrendszer felbomlását követően a fegyverkezés és a védelmi tervezés szükségszerüen új alapokra helyeződött.

\section{A hidegháborús tervrendszer}

A rendszerváltás előtt az ország háborúra való felkészítése az úgynevezett „szovjet modellre” épült, amely magába foglalta a fegyveres erők fejlesztését, a gazdaság mozgósítását, a lakosság és anyagi javak védelmét, polgári védelem felkészítését. ${ }^{28}$ Magyarországon a hidegháború alatt a védelemgazdaságot a központi tervutasításos rendszer jellemezte, amelyet a fegyveres erők tervezett háborús alkalmazásának rendeltek alá. Ez egy központosított ellátási rendszert jelentett, vagyis az ország a saját gazdasági lehetőségei szerint kellett, hogy biztosítsa a nemzeti fegyveres erő ellátását, amelyet nagyban segített a Varsói Szerződés tagállamaiban a fegyverek és hadfelszerelések homogenizálása, a fegyveres erők logisztikai rendszerének és a védelemgazdasági rendszereinek azonos felépítése. Az 1950 és 1968 közötti időszak jellemzője, hogy a centrális tervutasításos irányítási rendszer teljes mértékben megfelelt a háború időszakára vonatkozó tervezési követelményeknek. Az 1968-ban bevezetett új, a népgazdaság tervezéséről szóló 1972. évi Il. törvény alapján bevezetett tervezési rendszer kimondta, hogy a népgazdasági terv és a vállalati tervek közötti összhang a gazdasági ösztönzők és a jogi szabályozások útján teremtődik meg, ami nem képezheti az alapját egy háborús gazdaságirányítási rendszernek. 1980 után a gazdaságirányítási rendszer továbbfejlesztésének konkrét feladatait, ezen belül a védelemmel kapcsolatos gazdasági feladatok végrehajtásához szükséges intézkedések ki-

28 SZOKolovSZKIJ 1964, 7. fejezet. 
dolgozását az Állami Tervbizottság 1984. évi határozata írta elő, illetve kiadták az úgynevezett "Kék-könyvet”. ${ }^{29}$

Összességében elmondható, hogy az 1990-es évek előtti időszakban az Országos Tervhivatalban Működő Országos Honvédelmi Bizottság koordinálta az úgynevezett számítási év tervezést, amely az érintett szervek jelentései alapján biztosította a honvédelmi célú gazdasági igények és kapacitások megtervezését. A tervezésbe bevont közigazgatási szervek úgynevezett gazdaságmozgósítási tervekben alábontották az igényeket és kapacitásokat, figyelemmel a fegyveres összeütközés és a megelőzési veszélyeztetettségi időszakokra. A GM-terv tételesen tartalmazta a fegyveres erők, testületek összes igényét, vállalati részletezésben szabályozta a hadiipari termelésben érintettek és azok kooperációs partnerei termelési, szolgáltatási, ellátási feladatait.

A számítási év ${ }^{30}$ terve (továbbiakban: SZÉ-terv) - a már az idézett „Kék-könyv” szerint - mérlegszerűen előirányozta a fegyveres erők, a polgári lakosság védelméhez és ellátásához, illetve a nemzetgazdaság mủködéséhez szükséges eszközöket, figyelemmel a nemzetgazdaság anyagi és személyi erőforrásaira és lehetőségeire. ${ }^{31} \mathrm{Az}$ ágazati minisztériumok - feladat- és hatáskörök szerint végezték a polgári védelmi feladatok tervezési, szervezési, koordinálási, ellátásszervezési feladataikat. Például:

- az ipari ügyekkel foglalkozó minisztériumhoz tartoztak a háborúban tovább termelő gazdasági egységek;

- az építésüggyel foglalkozó minisztériumhoz tartoztak az óvóhelyekkel kapcsolatos feladatok;

- az oktatásüggyel foglalkozó minisztériumhoz tartoztak az oktatás-neveléssel, a nagy értékü műkincsek védelmével összefüggő feladatok;

- a belkereskedelemmel foglalkozó minisztériumhoz tartozott az élelmiszer biztonság;

- a földművelésügyekkel foglalkozó minisztériumhoz tartozott a lakosság szükségellátásának feladatrendszere;

- honvédelmi minisztérium, illetve a Magyar Néphadsereg Anyagtervezési csoportfönökségéhez tartozott a polgári védelmi szervezetekbe beosztottak és a lakosság részére is, úgynevezett speciális importból származó anyagokkal (gázálarc, védőruha, mentesítő eszközök, müszerek stb.) kapcsolatos ellátásának tervezési feladata.

29 A népgazdaság háborúra történő felkészítésének és mozgósításának alapelvei. A HB 7/368/1986. sz. hat. melléklete, 1986.

30 A SZÉ-tervet ötévenként - a népgazdaság középtávú terveivel egyidejüleg - dolgozták ki. Ennek része volt:

- a hadfelszerelési termelési kapacitások átállítása, a termelés felfuttatása;

- a haditechnikai és hadfelszerelési termékek termelése és javítása;

- a kiemelt polgári termékek termelése;

- a legfontosabb építési, beruházási feladatok;

- a mezőgazdasági termények és termékek termelése és felvásárlása;

- a polgári lakosság szervezett ellátása keretébe tartozó termékek elosztása;

- az egészségügy előirányzatai, az egészségügy személyi, anyagi, technikai ellátása

- a fegyveres szervek, a népgazdaság szállítási, hírközlési igényeinek kielégítése;

- a Varsói Szerződés tagállamaival szemben fennálló kötelezettségeink teljesítése.

Az utolsó terv az 1991-1995-ös időszakra lett előkészítve. Az Országos Tervhivatal még kiadta a tervezési előírást (Tervezési előírás a népgazdaság 1991. számítási év tervének előkészítéséhez [OT-0328/IV/1989.]), és elkészült a központi tervfejezetek kidolgozásával, de a tervezési folyamat befejezésére már nem került sor.

31 https://docplayer.hu/36607090-5-a-gazdasagmozgositas-tervezese.html (A letöltés dátuma: 2018. 04. 11.) alapján. 
A hidegháborús polgári védelmi tervrendszer egy komplex rendszert alkotott. Az Általános Polgári védelmi terv rendkívüli állapot, valamint szükségállapot idején bekövetkező fegyveres cselekmények esetén végrehajtandó polgári védelmi feladatokat tartalmazta. Ehhez kapcsolódtak az úgynevezett résztervek. Áttanulmányozva a rendelkezésre álló szakirodalmakat - a teljesség igénye nélkül - az alábbi terveket, részterveket emelem ki:

- Elrejtési terv - a lakosság és az üzemi dolgozók részére meghatározott feladatokat tartalmazta.

- Védett létesítményekre, vagyis a vezetési pontokra vonatkozó tervek, amelyek az alábbiak:

- védett létesítmények háborús tervei,

- védett létesítmény készenlétbe helyezési terve,

- védett létesítmény háborús ellátási terve,

- védett létesítmény karbantartási terve,

- együttműködési tervek (hivatásrendek között),

- M zárolt készlet terv - háborús összeütközés esetére készletezett anyagok, illetve termelőeszközök, békeidőszakban fel nem használható készletek összeírása.

A polgári védelmi tervezés szintjei megegyeznek a veszélyelhárítási tervezés rendszerével, ${ }^{32}$ annak szintjei annak részlegesen megfeleltethetők.

\section{A statikus és dinamikus tervezés}

A Müszaki Katonai Közlöny 2018/4. számában megjelent A katasztrófavédelmi logisztikai tervezési rendszer a stratégiai tervezés része című cikkemben megállapítottam, hogy a tervezés egy olyan „autonóm tevékenység”, amely mögött bizonyos szintig nem áll tényleges műveleti feladat és ténylegesen akkor tud eredményes lenni, ha dinamikus és alkalmazkodó folyamatként képes szolgálni egy jövőbeli állapot elérését, a változó környezet figyelembevételével. ${ }^{33}$

A tervezés alapvetően a felkészülés időszakának kiemelt feladata, amelynek célja a bekövetkező esemény, helyzet, kezelésének alapelveit, módszereit, a legfontosabb teendőit rögzíteni. A hidegháborús és a rendszerváltást követő időszak tervezési módozatai eltérnek egymástól, alapvetően azért, mert más irányú fenyegetettség és gazdasági, társadalmi és politikai környezet állt fent.

A tervezési módszertanok között megkülönböztethetünk statikus és dinamikus tervezési módszertant. Az alábbi, 5. táblázatban összefoglaltam a két tervezési metodika közötti különbséget.

32 2011. évi CXXVIII. törvény 3. § 25. pont - veszélyelhárítási terv: katasztrófaveszély, valamint katasztrófa időszakában végrehajtandó katasztrófavédelmi feladatokat tartalmazó, központi, területi (fővárosi), települési (a fővárosban kerületi) és munkahelyi okmányrendszer.

33 HORVÁTH 2010, 124. 
5. táblázat. A hidegháborúban, illetve a rendszerváltás utáni időszakban a védelmi rendszer tervezésének főbb jellemzői $i^{34}$

\begin{tabular}{|c|c|c|}
\hline & Hidegháborús időszak & Rendszerváltást követő időszak \\
\hline Tervezés & $\begin{array}{l}\text { Statikus tervezés: a beavatkozás elöre meg- } \\
\text { határozott tervekben rögzítetten létezett. }\end{array}$ & $\begin{array}{l}\text { Dinamikus tervezés, amelynek során a tervezésben konkrét } \\
\text { védekezést segítő részlettervek kerülnek előtérbe a hagyomá- } \\
\text { nyos védelmi alaptervvel szemben. }\end{array}$ \\
\hline $\begin{array}{l}\text { Tervezés } \\
\text { iránya }\end{array}$ & $\begin{array}{l}\text { Elsősorban atom/hagyományos } \\
\text { háborúra készült. }\end{array}$ & $\begin{array}{l}\text { Nem az atom/hagyományos háború a valóságos veszély, } \\
\text { hanem előtérbe kerülnek egyéb fenyegetések (terrortámadás, } \\
\text { járvány, klímaváltozás miatti természeti csapás stb.). }\end{array}$ \\
\hline $\begin{array}{l}\text { Jogrendi } \\
\text { korlátozás }\end{array}$ & $\begin{array}{l}\text { Háborús fenyegetettség esetén minősített } \\
\text { időszak bevezetésével számolt. }\end{array}$ & $\begin{array}{c}\text { Minősített időszaki/különleges jogrendi időszak bevezetése } \\
\text { nem mindig szükséges feltétel. }\end{array}$ \\
\hline \multirow[t]{2}{*}{$\begin{array}{l}\text { Logisztikai } \\
\text { háttér }\end{array}$} & $\begin{array}{l}\text { Igényeket közvetlen módon elégítette ki. } \\
\text { (Például hadigazdaságra való átállás, állami } \\
\text { cégeken keresztül rendelkezésre álló eszkö- } \\
\text { zök igénybevétele, készletezés folyamatosan } \\
\text { történik stb.) }\end{array}$ & $\begin{array}{c}\text { Piacgazdaságra való áttérés nem biztosítja a védelem gazda- } \\
\text { sági igényeit. (Például import aránya növekedett, állami cégek } \\
\text { aránya lecsökkent, készletezés, szolgáltatások biztosítása } \\
\text { lebiztosításokkal történik stb.) }\end{array}$ \\
\hline & $\begin{array}{c}\text { Költségelszámolás/költséghatékonyság } \\
\text { jelentősége nem volt fontos tervezési } \\
\text { szempont. }\end{array}$ & $\begin{array}{c}\text { Megelözés felértékelődik a költségérzékenység okán, a vé- } \\
\text { dekezés költsége elsősorban az államot terheli, de lehetőség } \\
\text { van a védekezés után a károkozó felé, polgári peres eljárásban, } \\
\text { a költségeket érvényesíteni. }\end{array}$ \\
\hline Felelős & $\begin{array}{c}\text { Érdemi beavatkozó erő: katonaság, az egyéb } \\
\text { hivatásrendek/állami szervek közreműkö- } \\
\text { dők - formális kapcsolat. }\end{array}$ & $\begin{array}{c}\text { Bekövetkező fenyegetettsége szerinti felelősség, komplex } \\
\text { közremüködői részvétel - szaktudással rendelkezők csoport- } \\
\text { munkára épülő kapcsolat. }\end{array}$ \\
\hline
\end{tabular}

Forrás: a szerző szerkesztése

Áttekintve a fenti táblázatban leírtakat, véleményem szerint a dinamikus tervezési módszertan lehet a megfelelő a tényleges helyzethez történő rugalmas reagálóképességre irányuló tervek kidolgozásához. A dinamikus tervezés föbb jellemzői közé tartoznak az alábbiak:

- operativitás: a hangsúly az operatív intézkedések meghatározásán van, nem pedig statikus tervezésre jellemző teljes körű alapterven;

- rugalmas szabályozottság: képesnek kell lennie egyfajta keretjellegű szabályozásként nem csak a különleges jogrendi időszakokban jelentkező feladatokat rugalmasan kezelni;

- együttműködés elve: kötelezés helyett inkább együttműködés ösztönzésére épít;

- új típusú piaci folyamatok illesztése: épít a modern gazdaság beszerzési folyamataira, úgymint anyag és szolgáltatás biztosítása, bizományosi készlet biztosítása stb.;

- felkészült szervezeti háttér: erősen épít a normál időszaki folyamatokra, amely a szervezet sajátossága, vagyis ismertek a veszélyhelyzetekhez szükséges ellenintézkedések feladatai, a lehetséges képesség-szolgáltatók listája, gyors kapcsolattartási és beszerzési rendszer üzemben tartása.

34 A Védelemgazdasági tervezés új módszertana módszertani alapelvek (tervezet) 2014. Elérhető: https://docplayer.hu/10940175-A-vedelemgazdasagi-tervezes-uj-modszertana.html (A letöltés dátuma: 2018. 04. 11.) leírtak alapján. 
A Hvt. 81. § (3) bekezdésében kapott felhatalmazás, az egyes miniszterek, valamint a Miniszterelnökséget vezető államtitkár feladat- és hatásköréröl szóló 212/2010. (VII. 1.) Korm. rendelet 37. §-ban meghatározottak és a honvédelemről és a Hvt. egyes rendelkezéseinek végrehajtásáról szóló 290/2011. (XII. 22.) Korm. rendelet 2. § (1) bekezdésében meghatározott feladatkörében eljáró honvédelmi miniszterrel egyetértésben - Magyarország belügyminisztere kiadta a belügyminiszter feladatkörét érintő ágazati honvédelmi feladatokról szóló 16/2013. (V. 9.) BM rendeletet (továbbiakban: BM rendelet).

A BM rendelet 2. §-a kimondja, hogy a belügyminiszter irányítása alatt álló rendvédelmi szervek fel kell hogy készüljenek a NATO Válságreagálási Rendszerével ${ }^{35}$ összhangban álló Nemzeti Intézkedések Gyűjteményében ${ }^{36}$ meghatározott honvédelmi feladatok teljesítésére.

A rendvédelmi szerveknek úgy kell kialakítani az irányítási, tervezési, szervezési és végrehajtási rendszereiket, hogy képesek legyenek együttműködni és támogatni a Magyar Honvédséget, valamint a szövetséges fegyveres erőket mindazon feladatok végrehajtásában, amelyek összefüggnek saját feladatrendszerükkel, valamint a lakosság és az anyagi javak védelmével és biztonságával. El kell látniuk a befogadó nemzeti támogatással kapcsolatos feladataikat, részt kell venniük a fegyveres összeütközések időszakában végrehajtandó polgári védelmi feladatok ellátásában, képesnek kell lenni együttműködni a védelmi igazgatás szerveivel a honvédelmi feladatok ellátásában, amelyeket a honvédelmi intézkedési tervben rögzíteni kell. ${ }^{37}$

\section{Honvédelmi Intézkedési Terv}

A hivatásos katasztrófavédelmi szerv vezetője - a fentiekkel összehangban - elkészíti a Honvédelmi Intézkedési Tervét ${ }^{38}$ (továbbiakban: terv). A tervben meghatározzák azt az alapvetést, miszerint a hivatásos katasztrófavédelmi szervek, és a polgári védelmi szervezetek fegyveres összeütközés során ellátja az alaprendeltetési feladatait, valamint kizárólag humanitárius, lakosságvédelmi, illetve segítségnyújtási, lakosság túléléséhez szükséges feladatokat lát el, hadmüveleti tevékenységben nem vesznek részt.

A terv biztosítéka annak az állam által garantált célnak a teljesítése, amely az Alaptörvényben meghatározott különleges jogrendi időszakban végrehajtandó honvédelmi feladatok végrehajtását teszi lehetővé, ezáltal garantálva Magyarország szuverenitását és biztonságát a katonai jellegü eseményekkel, valamint válságokkal szemben.

35 278/2014. (III. 21.) HM utasítás 2. § f) pont - „NATO Válságreagálási Rendszer: a különböző fokozatú válságkezelési és szükség esetén kollektív védelmi feladatok előkészítése érdekében a Szövetség készültségi és tervezési rendje."

36 278/2014. (III. 21.) HM utasítás 15-17. § alapján - A Nemzeti Intézkedések Gyűjteménye megelőzést szolgáló válságreagálási mủveletek előkészítését és végrehajtását támogató, illetve a terrorfenyegetettség biztonsági riasztási fokozataival összefüggő intézkedéseket tartalmazó eljárásrendek gyűjteménye.

37 16/2013. (V. 9.) BM rendelet 2. § (2) bekezdés.

38 A Honvédelmi Intézkedési Terv a 2011. évi CXII. tv. 27. § (2) bekezdése a) alpontja alapján „nem nyilvános” minősítésű. 


\section{A veszélyelhárítási terv mint a katasztrófavédelmi tervezés alapja, jellemzői}

A katasztrófavédelmi tervezéssel összefüggően szükséges a veszélyelhárítási tervezéssel kapcsolatos szabályozások rövid áttekintése. A veszélyelhárítási tervezés szabályait, a tervkészítésre kötelezettek körét, a tervek tartalmát, illetve a tervek jóváhagyási rendjét a Kvt. végrehajtásáról szóló 234/2011. (XI. 10.) Korm. rendelet VI. fejezete (továbbiakban: rendelet) tartalmazza. Ezeknek a terveknek a kidolgozása a polgári védelmi feladatok közé tartozó ${ }^{39}$ veszélyelhárítási tervezés folyamatát jelenti. A veszélyelhárítási tervezés szintjeit a rendelet 25 . § (2) bekezdése az alábbiakban határozza meg:

- a települési (a fővárosban kerületi) veszélyelhárítási terv;

- a munkahelyi veszélyelhárítási terv;

- a hivatásos katasztrófavédelmi szerv helyi szervének összesített terve;

- a területi (fővárosi) veszélyelhárítási terv;

- központi veszélyelhárítási terv (továbbiakban együtt: tervek).

A rendelet meghatározza az egyes katasztrófavédelmi (veszélyeztetettségi) osztályba ${ }^{40}$ sorolás szabályait, valamint a szükséges anyagi készlet meglétével kapcsolatos követelményeket is.

39 Kvt. 52. § j) pont szerint.

40 Rendelet 24. § alapján osztályba sorolás:

- „I. osztályba kell sorolni azokat a településeket, amelyek a) közvetlenül veszélyeztetettek az atomerőmű 3 km-es és a kutatóreaktor 1 km-es körzetében, $b$ ) a Kat. IV. fejezetének hatálya alá tartozó üzem által veszélyeztetettek és külső védelmi terv készítésére kötelezettek, c) az egyes veszélyeztető hatások kockázatbecslése és a kockázati mátrixban történő elhelyezése alapján a 2. melléklet b) pontja szerinti I. besorolást kapják, illetve d) területén az egyes veszélyeztető hatások egymásra gyakorolt és együttes hatására tekintettel indokolt a települést fokozottabb védelemben részesíteni.

- II. osztályba kell sorolni azokat a településeket, amelyek a) az atomerömű által közvetetten veszélyeztetettek (3-30 km közötti területen lévő), b) a Kat. IV. fejezetének hatálya alá tartozó üzem által veszélyeztetettek és külső védelmi terv készítésére nem kötelezettek, illetve $c$ ) az egyes veszélyeztető hatások kockázatbecslése és kockázati mátrixban történő elhelyezése alapján a 2. melléklet b) pontja szerinti II. besorolást kapják.

- III. osztályba kell sorolni azokat a településeket, amelyek a) a Kat. IV. fejezetének hatálya alá nem tartozó üzem által a veszélyes anyagok környezetbe kerülése esetén veszélyeztetettek, b) az egyes veszélyeztető hatások kockázatbecslése és a kockázati mátrixban történő elhelyezése alapján a 2. melléklet b) pontja szerinti III. besorolást kapják." 
6. táblázat. Az egyes katasztrófavédelmi osztályokhoz tartozó induló katasztrófavédelmi készletek státusza

\begin{tabular}{|c|c|c|c|}
\hline & I. osztály & II. osztály & III. osztály \\
\hline 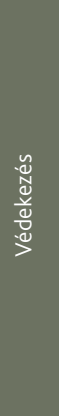 & $\begin{array}{l}\text { a) különleges felszerelések és kikép- } \\
\text { zett szakértők (önkéntes mentő- } \\
\text { szervezetek) bevonásának tervezése } \\
\text { és begyakoroltatása; } \\
\text { b) a kockázatbecslésnek megfele- } \\
\text { lően a polgári védelmi szervezetek } \\
\text { megalakítása; } \\
\text { c) a karitatív és más önkéntes, hu- } \\
\text { manitárius feladatot ellátó szervek } \\
\text { bevonásának tervezése és begya- } \\
\text { koroltatása }\end{array}$ & $\begin{array}{l}\text { a) különleges felszerelések és ki- } \\
\text { képzett szakértők (önkéntes } \\
\text { mentőszervezetek) bevonásá- } \\
\text { nak tervezése és begyakorol- } \\
\text { tatása; } \\
\text { b) a kockázatbecslésnek meg- } \\
\text { felelően egyes polgári védelmi } \\
\text { szakalegységek megalakítása; } \\
\text { c) a karitatív és más önkéntes, } \\
\text { humanitárius feladatot ellátó } \\
\text { szervek bevonásának ter- } \\
\text { vezése }\end{array}$ & $\begin{array}{l}\text { a) kizárólag a védekezési feladatok } \\
\text { ellátásához szükséges polgári } \\
\text { védelmi szakalegységek meg- } \\
\text { alakítása, } \\
\text { b) önkéntes segitők, karitatív szer- } \\
\text { vezetek bevonásának tervezése }\end{array}$ \\
\hline 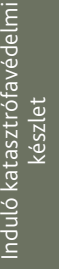 & $\begin{array}{l}\text { teljes induló katasztrófavédelmi } \\
\text { készlet megléte }\end{array}$ & $\begin{array}{l}\text { teljes induló katasztrófavédelmi } \\
\text { készlet megléte }\end{array}$ & $\begin{array}{c}\text { induló katasztrófavédelmi készlet } \\
\text { tervezése }\end{array}$ \\
\hline
\end{tabular}

Forrás: Rendelet 2. számú melléklet 2. pont c) táblázat alapján kivonatolta a szerzó

A tervezés feladatának megkönnyítése érdekében a rendelet 2. számú melléklete tartalmazza a veszélyelhárítási terv kötelező tartalmi elemeit. A tervezéssel és a logisztikai feladatokkal kapcsolatban a d) pont meghatározza többek között:

- a hivatásos katasztrófavédelmi szervek készenlétbe, a köteles polgári védelmi szervezetek alkalmazási készenlétbe helyezését;

- az egyéni védőeszközökkel és a szükséges védőfelszerelésekkel történő ellátás rendjét;

- a működéséhez szükséges anyagi készletek biztosításának rendjét, ami történhet saját szervezeten belül rendelkezésre álló, illetve lebiztosított formában;

- a logisztikai feladatok, így a szállításhoz, mentéshez szükséges anyagi készletek, továbbá az élelmiszer, ivóvíz, egészségügyi ellátás, a pihentetés és váltás feltételeinek, a gazdasági-anyagi szolgáltatások biztosításának rendjét;

- a lakosság védelmével összefüggésben egyéni védőeszközökkel, szükség-védőeszközökkel való ellátás rendjét;

- a vizek kártételei elleni védekezésben, a menekültek ideiglenes elhelyezésében, ellátásában, a nemzetközi segítségnyújtás ellátásában való közreműködés rendjét. ${ }^{41}$

41 Rendelet 2. számú melléklet 2. pont d) pont alapján. 


\section{A védelmi tervezés alapvetö elvei, követelményei}

Kiindulva a különböző védelmi tervezési formák logikájából azok kidolgozásához az alábbi tervezési elveket és követelményeket kell figyelembe venni:

- az ország egészére vonatkozóan reális értékeléssel kell rendelkezni a várható veszélyek fajtáiról, az ellenséges támadások irányáról, az alkalmazásba vehető támadó harceszközökről és azok pusztító hatásáról;

- elemezni kell az infrastruktúrát érintő várható rombolás mértékét, annak lehetséges mélységét;

- fel kell mérni a veszélyeztetett lakosságszámot, az objektumok, intézmények, ipari létesítmények mennyiségét, fajtáit és lehetséges hatásait, ha azok müködése megszűnik;

- dinamikus módszertan alapján készített tervekkel kell rendelkezni a védelem úgynevezett harcászati zónájában élők kiürítésére, befogadására, élelmezésére, egészségügyi ellátására, és fel kell készíteni a befogadó területeken jelentkező feladatok végrehajtására;

- fel kell mérni az ország védelmi felkészüléséhez kapcsolódó gazdaságmozgósítási lehetőségeket, igényeket, illetve az állami tartalékok meglétét, elérhetőségét.

A fentiek alapján összességében elmondható, hogy az alapvető védelmi terveket már a béke (felkészülési) időszakban el kell készíteni, és a feladatok végrehajtáshoz szükséges szervezeti és erőforrás-feltételeket folyamatosan ki kell alakítani. Természetesen, a polgári védelem háborús feladatai pontosan nem tervezhetők, ezért a katasztrófavédelmi (veszélyelhárítási) terveket úgy kell kidolgozni és a képességeket kialakítani, hogy az kellő rugalmassággal alkalmazható legyen fegyveres küzdelem esetén is. Fontos, hogy a kidolgozás során a tervezési elvek és követelmények folyamatosan érvényesüljenek, az elkészült tervek legyenek reálisak és naprakészek.

\section{A hivatásos katasztrófavédelem honvédelmi és polgári védelmi feladatai a fegyveres összeütközés időszakában, a jogszabályok tükrében}

A honvédelemről és a Magyar Honvédségről, valamint a különleges jogrendben bevezethető intézkedésekről szóló 2011. évi CXIII. törvény 81. § (3) bekezdésében kapott felhatalmazás alapján a belügyminiszter a 16/2013. (V. 9.) BM rendeletben szabályozta a belügyminisztérium irányítása alá tartozó szervezetek honvédelmi feladatait és az ezzel kapcsolatos kötelezettségeket. A hivatásos katasztrófavédelmi szervek honvédelmi feladatait a BM rendelet 6 . §-a az alábbiak szerint rögzíti:

„A hivatásos katasztrófavédelmi szervek honvédelmi feladataik teljesítése során:

a) végzik a hivatásos katasztrófavédelmi szerveknek, a polgári védelmi szervezeteknek, a közbiztonsági referenseknek és a mentőalakulatok tagjainak a honvédelmi feladatok végrehajtására történő felkészítését, valamint részt vesznek azok tevékenységének koordinálásában, 
b) részt vesznek a légiriasztás elökészítésében és annak végrehajtásában,

c) közreműködnek az elsötétítési rendszabályok bevezetésének alkalmazásában,

d) részt vesznek a menekültek elhelyezésében,

e) közremüködnek a lakosság túléléséhez szükséges nélkülözhetetlen létesítmények müködőképességének fenntartásában, készenlétbe helyezésének feladataiban, továbbá

f) részt vesznek a hadműveleti területről kimenekített lakosság regisztrálásában."

Fegyveres összeütközések esetén, a hivatásos katasztrófavédelmi, valamint a polgári védelmi szervezetek közreműködnek a „Befogadó Nemzeti Támogatás” keretében a megsegítő szövetséges katonai erők hazai fogadásában és elhelyezési feladatainak végrehajtásában.

A Befogadó Nemzeti Támogatás (továbbiakban: BNT) lényege, hogy különleges jogrend időszakában a fogadó nemzet területén elhelyezkedő, működő, illetve átvonuló szövetséges erők számára polgári és katonai segítséget kell nyújtani. A NATO-vezetésű erők Magyarország területén való elhelyezését, átvonulását, illetve alkalmazását biztosító befogadó nemzeti támogatás tervezésére és végrehajtására az Országgyülés vagy a kormány által jóváhagyott NATO-múveletek során a befogadó nemzeti támogatás részletes kormányzati feladatairól szóló 55/2010. (III. 11.) Korm. rendelet alapján kell eljárni.

A fentieken túl, a hivatásos katasztrófavédelmi szervezetek közreműködnek - az alaprendeltetés szerinti feladatuk ellátása mellett - az alábbi támogatási feladatok végrehajtásában:

- az eszközök elhelyezési igényeinek biztosításában és megvalósításában;

- a befogadóhelyek kialakításában, berendezésében, erők ellátásában;

- a beérkező erők ellátásához szükséges anyagok szállításában;

- szükség esetén, igény szerint, biztosítják a szakmai támogatási feladatok végrehajtásához a katasztrófavédelmi mobil laboratóriumok felderítő képességeit, valamint a tűzoltóságok erő- és eszközállományának részvételét.

A hatályos polgári honvédelmi törvény alapján, a fegyveres összeütközéssel kapcsolatos feladatok (háborús feladatok), végrehajtási időszakok szerinti csoportosítását a 6. táblázat tartalmazza. A három időszakon belül végrehajtandó feladatok, a végrehajtás helyszíne szerint, (katonai műveleti terület, hátország) további két csoportba sorolhatók. 


\section{7. táblázat. Polgári védelmi feladatok időszaki csoportosítása}

\begin{tabular}{|c|c|c|c|c|c|c|}
\hline \multirow{2}{*}{$\begin{array}{l}\text { Feladatok a hatályos Hvt. alapján történő } \\
\text { kivonatolás szerint }\end{array}$} & \multicolumn{2}{|c|}{$\begin{array}{l}\text { Felkészülési idöszak } \\
\text { feladatai }\end{array}$} & \multicolumn{2}{|c|}{$\begin{array}{l}\text { Fegyveres összeütközés } \\
\text { idöszakának feladatai }\end{array}$} & \multicolumn{2}{|c|}{$\begin{array}{l}\text { Eredeti helyzet visszaál- } \\
\text { lítási időszakának feladatai }\end{array}$} \\
\hline & 离 & 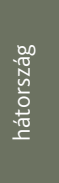 & 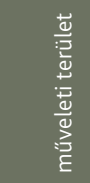 & 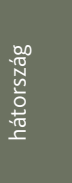 & 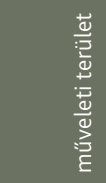 & 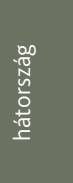 \\
\hline riasztás & $x$ & $\mathrm{x}$ & $x$ & $\mathrm{x}$ & $\mathbf{x}$ & $\mathrm{x}$ \\
\hline $\begin{array}{l}\text { a lakosság kimenekítése, kitelepítése } \\
\text { és befogadása, visszatelepítése }\end{array}$ & $x$ & $\mathbf{x}$ & & $x$ & $x$ & \\
\hline $\begin{array}{c}\text { közremüködés a menekültek elhelyezésé- } \\
\text { ben és ellátásában, továbbá a tüzoltásban, } \\
\text { és a nemzetközi szerződésekből adódó tájé- } \\
\text { koztatás és kölcsönös segítségnyújtás felada- } \\
\text { tainak ellátásában }\end{array}$ & $x$ & $\mathbf{x}$ & $x$ & $x$ & $x$ & $x$ \\
\hline $\begin{array}{l}\text { vegyi és sugármentesités, fertőtlenités } \\
\text { és ezekkel kapcsolatos óvintézkedések }\end{array}$ & $x$ & $x$ & & $x$ & $\mathbf{x}$ & $x$ \\
\hline $\begin{array}{c}A B V \text { - és tömegpusztító fegyverek elleni } \\
\text { védelem }\end{array}$ & $x$ & $\mathbf{x}$ & & $\mathrm{x}$ & $x$ & $x$ \\
\hline $\begin{array}{l}\text { a feladatok végrehajtásához szükséges } \\
\text { kiegészítő tevékenységek (tervezés, szervezés, } \\
\text { együttmüködés megszervezése) }\end{array}$ & $x$ & $x$ & $\mathbf{x}$ & $\mathrm{x}$ & $x$ & $\mathrm{x}$ \\
\hline védelmi célú építmények fenntartása & & $x$ & $\mathbf{x}$ & $x$ & $x$ & $x$ \\
\hline $\begin{array}{c}\text { gondoskodás a létfenntartáshoz szükséges } \\
\text { anyagi javak és a létfontosságú } \\
\text { infrastruktúrák védelméről }\end{array}$ & & $x$ & & $x$ & $x$ & $x$ \\
\hline $\begin{array}{l}\text { a halálos áldozatokkal kapcsolatos } \\
\text { halaszthatatlan intézkedések }\end{array}$ & & & $x$ & & & \\
\hline $\begin{array}{c}\text { a kárterület megjelölése, a mentés, az első- } \\
\text { segélynyújtás, a mentesítés és a fertőtlenítés, } \\
\text { és az ezekkel összefüggő ideiglenes helyre- } \\
\text { állítás }\end{array}$ & & & & $x$ & $x$ & $x$ \\
\hline
\end{tabular}

Forrás: a szerző szerkesztése

A táblázatból látható, hogy a feladatok nemcsak egy időszakhoz és helyszínhez köthetők, hanem gyakran több időszakban és területen jelennek meg, és a kialakult helyzetnek megfelelően kell azokat végrehajtani. 


\section{A polgári védelmi feladatok végrehajtásának struktúrája, az együttmüködés rendje}

A különleges jogrend kihirdetéséig az irányítás és a koordináció mindenkori legmagasabb szintje a kormány, a szükségállapot és a rendkívüli állapot idején a hatalmi centrum a Köztársasági Elnök és a Honvédelmi Tanács.

Jelenleg a polgári védelmi feladatok végrehajtásának szervezését és koordinálását a belügyminisztérium rendszerében országos irányító szervként, területi szervezeti egységein keresztül, a BM OKF végzi. A kormányzati szándék és akarat érvényesülése a védelmi igazgatás keretén belül, annak központi, területi, járási és helyi szervei útján valósul meg. A polgári védelmi feladatok megvalósulásának szintjei és szervezeti rendje az 1. ábrán látható.

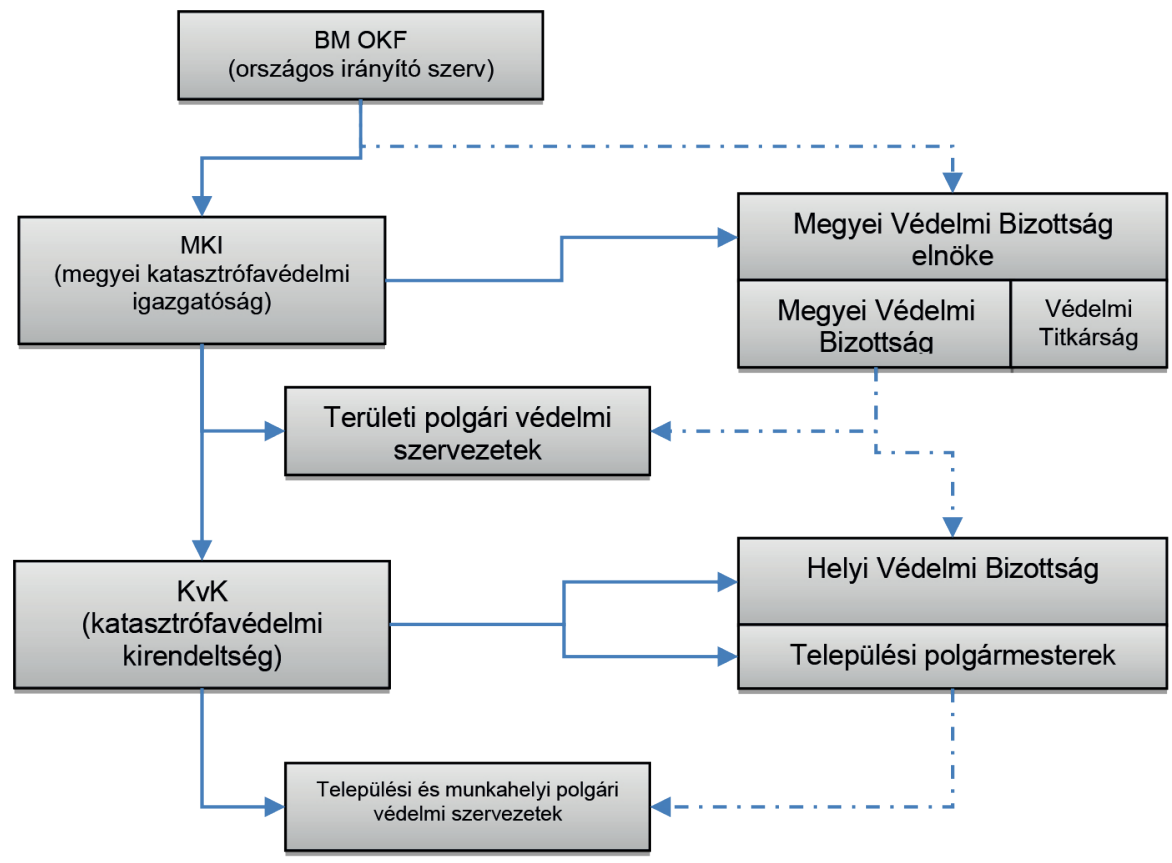

1. ábra. A polgári védelmi feladatok végrehajtásának egyszerüsített szervezeti rendje

Forrás: a szerző szerkesztése

A békeidőszaki felkészítések során az MH erők és a polgári védelmi szervezetek közötti együttmüködés alapvetően a Honvédelmi Minisztérium és a BM Országos Katasztrófavédelmi Föigazgatóság között létrejött együttmüködési megállapodás alapján történik. Területi szinten a kapcsolattartás a megyei (fővárosi) védelmi bizottságok katasztrófavédelmi elnökhelyettese és az abba delegált MH-képviselő útján történik. 
Fegyveres összeütközés időszakában az együttmüködés megvalósítására a Magyar Honvédség stratégiai szintű vezetési eleme kapcsolattartót biztosít a BM és/vagy a hivatásos katasztrófavédelmi szerv központi operatív munkaszervébe. A központi polgári védelmi szervezettel való együttműködés a fenti összekötőn és a fővárosi/megyei védelmi bizottságok katonatagjain keresztül valósul meg.

\section{Összefoglalás}

A cikk megírásának célja, hogy a védelmi szakemberek és kutatók figyelmét felhívja egy olyan védelmi területre, amely az utóbbi évtizedekben kevés figyelmet kapott. A háborús polgári védelmi feladatrendszerrel kapcsolatos kutatások és jogi szabályozások a rendszerváltás után háttérbe szorultak, ezért ez a cikk egy hiánypótló elemzésnek is tekinthető. Megírásához áttekintettem a polgári védelmi feladatok megtervezésével és végrehajtásával kapcsolatos elveket, követelményeket, illetve a kapcsolódó logisztikai támogató rendszer jelenlegi helyzetét.

Összességében megállapítható, hogy a polgári védelem alaprendeltetéséből adódó háborús feladatrendszer mellett, 1973. január 1. óta jelentek meg a békeidős, vagyis a katasztrófák elleni védekezési feladatok, oly módon, hogy a háborús felkészülési feladatok szintén jelen vannak, de végrehajtásuk még tervezési szinten is háttérbe szorult. A polgári védelem háborús feladatainak keretszintű szabályozása jogszabályi szinten megtörtént, de a feladatok végrehajtásához szükséges elemzések, tervezések és a képességek kialakítása nem történt meg.

Napjainkra a védelmi tervezés rendszere átalakult. A katasztrófavédelem területén a gyakorlatban elfogadott és alkalmazott tervek a veszélyelhárítással kapcsolatosak, amelynek alapja a települések veszélyeztetettségének felmérése és besorolása. Ehhez kötődnek a védekezéshez szükséges logisztikai készletek is. Célszerủ megoldás lenne, ha a szakemberek a veszélyelhárítási tervek készítése során figyelembe vennék a háborús feladatokat, valamint úgy alakítanák ki a polgári védelmi szervezetek képességeit, hogy azok alkalmasak legyenek fegyveres összeütközés esetén is a feladatok végrehajtására.

A kutatási eredményeim alapján az is bizonyossá vált, hogy a háborús polgári védelmi, valamint a katasztrófák elleni védekezés feladatai nagymértékben hasonlóak, átfedik egymást, csak a veszélyforrásokban és azok hatásaiban különböznek. Ezért a felkészülés és a képességek kialakítása nem lehet teljesen azonos, de lehetséges azok egymáshoz történő közelítése azáltal, ha a védelmi tervezési szempontjait és követelményeit helyesen választják meg és szakmailag következetesen alkalmazzák.

\section{Felhasznált irodalom}

GYÖRÖK László (2015): A hadszíntér-elökészítés lehetséges feladatai a XXI. század kihívásai tükrében. Müszaki Katonai Közlöny, 25. évf. 3. sz. Elérhető: https://mkk.uni-nke.hu/document/mkk-uninke-hu/2015_3_06_A\%20hadszinter\%20elokeszites\%20.pdf (A letöltés dátuma: 2018. 12. 20.) 
HORVÁTH Zoltán (2018): A katasztrófavédelmi logisztikai tervezési rendszer a stratégiai tervezés része. Müszaki Katonai Közlöny, 28. évf. 4. sz. 123-146. Elérhetö: https://docplayer.hu/115167211-Xxviiievfolyam-szam-a-katasztrofaved elmi-logisztikai-tervezesi-rendszer-a-strategiai-tervezes-resze. html (A letöltés dátuma: 2018. 12. 20.)

A katasztrófavédelem szervezetrendszere régió/kistérség szerinti átalakításának kérdéseiről, lehetőségeiről. BM OKF veszélyhelyzet kezelési főigazgató-helyettesi előterjesztés II. változata. 2003. 06. 23.

LAKATOS László (2014): A különleges jogrend és a honvédelem szabályozása. MTA Budapest, MTA Law Working Papers 2014/49. Elérhető: http://jog.tk.mta.hu/mtalwp (A letöltés dátuma: 2018. 12. 14.)

LAPOS Mihály (1988): A védelmi műveletek hadtápbiztosításáról. Hadtápbiztosítás, 21. évf. 2. sz. 16-21. Elérhető: http://epa.oszk.hu/03000/03059/00082/pdf/EPA03059_hadtapbiztositas_1988_2_016-021.pdf (A letöltés dátuma: 2018.12.14.)

MuHORAY Árpád (2017): A polgári védelem helye a modern katasztrófavédelemben. Hadmérnök, 12. évf. 2. sz. Elérhető: http://hadmernok.hu/172_15_muhoray.pdf (A letöltés dátuma: 2018. 12. 20.)

PATAKI Iván (1998): A polgári védelem a honvédelem rendszerének alkotóeleme. Hadmérnök, 8. évf. 3. sz. Elérhető: http://mhtt.eu/hadtudomany/1998/ht-1998-3-5.html (A letöltés dátuma: 2018. 03. 27.)

SzokolovszKIJ, V. D. (1964): Hadászat. Budapest, Zrínyi Katonai Kiadó.

То́тн Rudolf (2000): A Magyar Polgári Védelem fejlesztésének szükségessége, lehetséges iránya, a NATO tagság, a Magyar Honvédség korszerüsítése és a hazai katasztrófavédelmi rendszer helyzetének tükrében. PhD-értekezés. Budapest, ZMNE. Elérhetö: www.drhornyacsek.hu/publikaciok/doktori\%20 ertekezesek/Dokt.vegleges\%20osszesen.pdf (A letöltés dátuma: 2018. 12. 20.)

\section{Internetes források}

Benkő: Nem szabad túlzottan nyugodtnak lenni (2014). magyarnemzet.hu Elérhető: https://mno.hu/belfold/benko-nem-szabad-tulzottan-nyugodtnak-lenni-1214892 (A letöltés dátuma: 2018. 04. 11.)

A gazdaságmozgósitás tervezése (é. n.). Elérhető: https://docplayer.hu/36607090-5-a-gazdasagmozgositas-tervezese.html (A letöltés dátuma: 2018. 04. 11.)

A Védelemgazdasági tervezés új módszertana módszertani alapelvek (tervezet) (2014). Elérhetö: https:// docplayer.hu/10940175-A-vedelemgazdasagi-tervezes-uj-modszertana.html (A letöltés dátuma: 2018. 04. 11.)

\section{Jogforrások}

15/1936. számú honvédelmi miniszteri rendelet

15/1992. (I. 27.) Korm. rendelet a polgári védelemről

16/2013. (V. 9.) BM rendelet

1656/2012. (XII. 20.) Korm. határozat Magyarország Nemzeti Katonai Stratégiájáról

18/1995. (III. 18.) AB határozat

1935. évi XII. törvény a légvédelemröl

1976. évi I. törvény a honvédelemröl

1996. évi XXXVII. törvény a polgári védelemröl

2/1976. (VI. 17.) számú honvédelmi miniszteri rendelet

2004. évi CV. törvény a honvédelemröl és a Magyar Honvédségröl

2011. évi CXIII. törvény a Magyar Honvédségröl, valamint a különleges jogrendben bevezethető intézkedésekről 
2011. évi CXXVIII. törvény a katasztrófavédelemről és a hozzá kapcsolódó egyes törvények módosításáról 2041/1974. (XII. 11.) számú MT határozat a polgári védelemről

234/2011. (XI. 10.) Korm. rendelet a katasztrófavédelemről és a hozzá kapcsolódó egyes törvények módosításáról szóló 2011. évi CXXVIII. törvény végrehajtásáról

278/2014. (III. 21.) HM utasítás

290/2011. (XII. 22.) Korm. rendelet a honvédelemröl és a Magyar Honvédségröl, valamint a különleges jogrendben bevezethető intézkedésekről szóló 2011. évi CXIII. törvény egyes rendelkezéseinek végrehajtásáról

55/2010. (III. 11.) Korm. rendelet

6/1976. (III. 31.) MT rendelet

7/1992. (V. 19.) BM rendelet a honvédelemröl

85/1993. (VI. 1.) Korm. rendelet a tüzvédelem és a polgári védelem központi irányításáról

94/1998. (XII. 29.) OGY határozat Magyar Köztársaság biztonság- és védelempolitikai alapelveiröl 